\title{
An explanation and invitation: making space for conversation in the digital world
}

\author{
Hilary P. Grocott, MD • Gregory L. Bryson, MD
}

Received: 26 January 2015 / Accepted: 2 February 2015/Published online: 3 March 2015

(C) Canadian Anesthesiologists' Society 2015

In this issue of the Journal, ${ }^{1,2}$ and in the monthly issues to follow, some minor formatting changes will be apparent to those receiving print copies of the Journal. This month, readers will find two Letters to the Editor, each on their own page. The corresponding replies to these letters will also be on their own separate pages. The resulting extra "white space" on the printed page may cause some readers to wonder if there was an error in the printing process, while others may query the environmental sensitivity of the Journal. In fact, this change in layout was driven by a characteristic of our web-based world, the digital object identifier (DOI).

The DOI is an identifier of any entity - physical, digital, or abstract - on a digital network. It provides "persistent and actionable identification and interoperable exchange of managed information." A In plain language - a DOI is a unique clickable name. Take for example an editorial published in the December 2014 issue of the Journal. ${ }^{3}$ The DOI for this work is 10.1007/s12630-014-0243-5. An interested person entering this string into a Google search box is linked directly to the article on the Journal's web

This submission was handled by Dr. Philip M. Jones, Associate Editor, Canadian Journal of Anesthesia.

Cette soumission a été traitée par Dr Philip M. Jones, rédacteur associé, Journal canadien d'anesthésie.

H. P. Grocott, MD (ه)

Departments of Anesthesia \& Perioperative Medicine and Surgery, University of Manitoba, St Boniface Hospital, CR3008-369 Tache Avenue, Winnipeg, MB R2H 2A6, Canada e-mail: hgrocott@sbgh.mb.ca

G. L. Bryson, MD

Department of Anesthesiology, University of Ottawa, Ottawa, ON, Canada page. DOIs are important to readers, writers, and publishers as they represent the citeable unit in the National Library of Medicine (i.e., PubMed).

In years past, correspondence regarding an article published in the Journal appeared on a separate new page within the Journal and the original author's reply appeared immediately beneath. Although this would seem to be a logical way to organize the Journal, it had the disadvantage that the author's reply was considered part of the letter itself, and therefore, it was not issued its own DOI. By tagging the reply with a DOI, this work is now a digital object in its own right, searchable electronically, and referenced in PubMed. A quirk of our publication production process requires that each DOI appear on a separate page (fortunately, there is no additional cost to the Society for publishing this seemingly extra space).

Some may ask "Why bother with all of this?" The answer: One of the goals of the Journal is to create conversation around the science of anesthesia, pain, perioperative medicine, and critical care. We view this exchange of ideas as a benefit to our Society members and our other readers. This change in format now allows for participants in this important academic discourse to be accorded better academic credit (i.e., a citation). Furthermore, this layout also benefits the Journal by increasing the volume of material that produces a DOI, which can have a significant impact on both our publishing revenue as well as our impact factor.

This editorial commentary is intended to be an explanation for this minor though noticeable change in the printed version of the Journal. But it also serves as an

\footnotetext{
$\overline{\mathrm{A}}$ The $\mathrm{DOI}^{\circledR}{ }^{\circledR}$ system. The DOI Handbook. Available from URL: http://www.doi.org/doi_handbook/1_Introduction.html (accessed January 2015).
} 
invitation to encourage readers of the Journal to become engaged in the academic discourse and post-publication peer review that is needed for further validation of the scientific process. We enthusiastically encourage submissions of all sorts to the Journal, including letters of correspondence as well as their replies.

\section{Une explication et une invitation: faire place à la conversation dans le monde numérique}

Dans ce numéro du Journal ${ }^{1,2}$ et dans les numéros qui vont suivre au cours des prochains mois, quelques changements de présentation seront visibles par ceux qui en reçoivent les exemplaires imprimés. Ce mois-ci, les lecteurs trouveront deux Lettres au Rédacteur, chacune sur sa propre page. Les réponses correspondant à ces lettres se trouveront également sur des pages distinctes. Les espaces blancs supplémentaires qui en résultent sur les pages imprimées pourront faire se demander aux lecteurs s'il n'y a pas eu d'erreur au cours du processus d'impression, tandis que d'autres se demanderont si le Journal est sensible aux questions environnementales. En fait, cette modification de la maquette a été rendue nécessaire par une caractéristique de notre monde basé sur le Web: l'identifiant d'objet numérique ou DOI (digital object identifier).

Le DOI est un identifiant de toute entité, physique, numérique ou abstraite, présente sur un réseau numérique. Il procure une «identification permanente et utilisable, ainsi qu'un échange interopérable d'informations gérées ». A En langage clair, un DOI est un nom unique sur lequel on peut cliquer. Si l'on prend l'exemple d'un éditorial publié dans le numéro de décembre 2014 du Journal, ${ }^{3}$ son DOI est 10.1007/s12630-014-0243-5. La personne intéressée entrant cette chaîne de caractères dans une case de recherche de Google trouvera immédiatement le lien vers l'article sur la page Web du Journal. Les DOI sont importants pour les lecteurs, les auteurs et les éditeurs, car ils représentent une unité qui peut être citée dans la National Library of Medicine (c'est-à-dire, PubMed).

$\mathrm{Au}$ cours des dernières années, la correspondance concernant un article publié dans le Journal apparaissait sur une nouvelle page et la réponse de l'auteur était publiée immédiatement en dessous. Bien que cela ait pu sembler une façon logique d'organiser le Journal, cette méthode avait l'inconvénient de faire passer la réponse de l'auteur pour une partie de la lettre proprement dite et, en conséquence, n'avait pas son propre DOI. En attribuant un DOI à la réponse proprement dite, ce document devient maintenant un objet numérique distinct qu'il est possible de rechercher par voie électronique et qui est référencé dans PubMed. Une bizarrerie de notre processus de production de la publication fait que chaque DOI parait sur une page différente (heureusement, la publication de cet espace apparemment ajouté n'entraîne pas de coûts supplémentaires pour la Société).

Certains peuvent se demander pourquoi se donner tant de mal. Voici la réponse à cette question: l'un des objectifs du Journal est de créer une discussion autour de la science de l'anesthésie, de la douleur, de la médecine périopératoire et des soins intensifs. Pour nous, cet échange d'idées profite aux membres de notre Société ainsi qu'à nos autres lecteurs. Ce changement de format permet maintenant d'attribuer un meilleur crédit (c'est-à-dire, une référence) à ceux qui participent à cet important débat académique. En outre, cette mise en page profite également au Journal en augmentant le volume de matériel produisant un DOI, ce qui peut avoir un impact significatif sur, à la fois, nos recettes de publication et notre facteur d'impact.

Ce commentaire éditorial se veut d'abord une explication de ce changement, mineur mais néanmoins notable, dans la version imprimée du Journal. Il veut aussi être une invitation lancée aux lecteurs de notre Journal pour les inciter à se lancer dans des débats académiques et dans la revue par les pairs après publication qui sont nécessaires à une validation plus poussée du processus scientifique. Nous encourageons très vivement les soumissions de tous types au Journal, y compris les lettres de correspondance et les réponses à ces dernières.

Conflicts of interest None declared.

Conflits d'intérêts Aucun déclaré.

\section{References}

1. Lokoff A, Lokoff $P$. Unrecognized arterial cannulation. Can J Anesth 2015; 62: this issue. DOI: 10.1007/s12630-015-0319-x.

2. Jones RK. In reply: Unrecognized arterial cannulation due to the backflow feature of the BD Insyte ${ }^{\mathrm{TM}}$ Autoguard $^{\mathrm{TM}} \mathrm{BC}$ cannula. Can J Anesth 2015; 62: this issue. DOI: 10.1007/s12630-0150320-4.

3. Grocott HP. Publishing in science: a collaborative process. Can $\mathrm{J}$ Anesth 2014; 61: 1063-7. 